\title{
Integration of Penal and Non-Penal Acts in Tackling Santet
}

\author{
Baginda Khalid Hidayat Jati ${ }^{1}$, Endri ${ }^{2}$ \\ khalidhidayat29@gmail.com ${ }^{1}$, endrieshaemha@gmail.com² \\ Universitas Diponegoro, Jl.Imam Bardjo, SH. No 1 Semarang ${ }^{1}$, \\ Universitas Maritim Raja Ali Haji, Jl. Raya Dompak, Tanjung Pinang ${ }^{2}$
}

\begin{abstract}
Santet considered as a prohibited action by some Indonesian because the damage that it costs. Until now, the law enforcement regarding this acts is quite difficult to process since it's relation to things that are irrational. Therefore, the problem in this paper focused on how the positive criminal law in Indonesia enforce against witchcraft acts, and how important is the integration of penalties and non-penalties way in dealing with witchcraft crimes in the future. This research uses literature study for analyzing the object of study. At present witchcraft criminal law enforcement tends consist of partial law enforcement with costly procedure. The future prevention is needed by integrating between non-penal and penal acts. The non-penal acts requires participation of public and law enforcement officials to prevent, condemn acts of witchcraft, and processed to the criminal justice enforcement as a final step, if the prevention cannot be done.
\end{abstract}

Keyword: non penal efforts, criminal acts, witchcraft, integration

\section{Introduction}

Witchcraft or santet in Indonesia is a belief of some people in certain areas that certain objects could be possessed with some mystical being such as jinn which could cause diseases, hurt or even create death to the targeted victim. In some areas, people still believe that acts of witchcraft will bring a negative impact on their victims and could be used as a means to take revenge. The reaction of this traditional community to acts of witchcraft are varied, some might reported this action to law enforcement officials, but there were also those which provoked and start to persecuted the suspect by themselves which could resulted in death to the suspected perpetrators of witchcraft. There are some areas that are still disputable of practicing this mystical acts such as in certain location within Java.

When talking about witchcraft in Java, Banyuwangi is one of the places that consider as one of the center of witchcraft practice. Banyuwangi was suffering from a grief in July 1998 to December 1998 because about 116 people were accused of being witch doctors. This people that consisted with some local kyai or spiritual figure, were killed by some masked vigilante groups in a witch hunt. There were several killings that happened at that time, for example a group of disguised masses broke at night into the house of the suspected witch doctors, then killed them. There are also some cases which carried out during the day and involving the local villagers, namely by accusing and confronting the target with accusations of being a shaman, so that the villagers became furious and helped to torture and kill the accused. Not less than a year 
when this incident happened, the case of torture and massacre of someone related to the accusation of a dukun santet also broke out in 1999 in Pangandaran [1].

One of the local tribe in Banyuwangi, Using Tribe, divides witchcraft or santet into three categories, namely (1) Ilmu hitam is a magic that usually contain many negative effects since it used for harming people, and kills people; (2) Ilmu merah is a magic that used for attract opposite sex and used especially regarding in sexual matters; (3) Ilmu kuning is the magic which have purpose for creating aura of authority to deal with subordinates or the public in general; and (4) Ilmu putih is the magic that counter the other three magic. One of the famous santet that being used by people is Jaran Goyang, that entered into the second kind of magic which is a magic that directed towards sexual and compassion, this is somehow have certain similarity with Islamic teachings known as mahabbah [1].

Santet is an acronym for 'mesisan banthet' which means 'to became broken' and 'mesisan ganthet' which means 'to became one'. Santet or witchcraft in the perspective of "mesisan banthet", are happened when a couple who love each other became separated. Meanwhile, the other perspective of "mesisan ganthet", happened when two people who are not in love with each other started to became united in a unnatural ways. Like in some Javanese community, Using Tribe usually practiced arranged marriage. This 'mesisan banthet' witchcraft will come in handy if for somehow one of the children already has a lover. From this kind of family tradition, witchcraft culture then developed and flourish within the community [1]

Someone who wants to do witchcraft for both good and evil things can come to a witchcraft expert or in another language ask dukun for help. Santet itself is basically a phenomenon that is very close to the lives of various community traditions in Indonesia. In the Kamus Besar Bahasa Indonesia, santet can also be interpreted as magic [2], santet itself has a English translation as witchcraft. Based on Merriam Webster's Dictionary, witchcraft is defined as the use of sorcery or magic [3]. There is also another name related to this kind of irrational matters which is 'occult'. 'Occult' word comes from English language, which has a mysterious meaning, or something that is hidden from normal view. This sentence is also often emphasized by the use of magic, astrology, or other systems that claim to be able to use secret knowledge or supernatural powers [4]. Occultism itself has the meaning of teachings related to various kinds of mystical things, hidden, and can not be digested with human reason [5].

Based on those definition, if this magical power is being used for the benefit of the community, for example helping to unite a family or someone with another, or helping to avoid bad luck in life then it wouldn't be a problem at all, but if this magical power is used to hurt, damage, creating chaos and even death then it must addressed both by the community itself and by the state as a criminal action. Until now the handling of witchcraft within several community in Indonesia usually propagated by incitement, issues and hoaxes which being blown out and resulting in persecution and expulsion of those suspected of doing witchcraft. Thus the state must be present to deal with this uncontrolled anger, while enforcing the law against perpetrators of witchcraft which means protecting the public from crime. Likewise, the state also need to educate the public so as not to play a role in judging suspected perpetrators of witchcraft. The policy to tackle crime especially witchcraft must look at the interests of society and individuals.

Crime prevention policy within the criminal law is divided into two, namely the penal policy and non-penal policy. The penal policy is more on repressive actions after the crime being committed, while non-penal policy focus on the preventive aspect. Both of these facilities have their own weaknesses that result in ineffectiveness in law enforcement, specifically in the 
crime of witchcraft. Based on that, this research is considered to be important to being carried out, so that the law enforcement of criminal acts of witchcraft will be integrated both in penal and non-penal policies.

According on the background stated above, the focus of the study is limited into two problems, namely on the criminal law enforcement current regulation in tackling the crime of witchcraft in Indonesia positive law and on how should be the integration of non-penal and penal policies in tackling criminal acts of witchcraft in the future.

\section{Methods}

The research method that will be used is normative legal research. In normative legal research, a statutory approach within government policies is used. Normative legal research is done by reviewing or examining secondary data in the form of secondary legal sources, which made by compassionate the law as a set of rules or positive norms in the regulatory system governing the society. Normative legal research is legal inspection that places law as a norm structure system. This system is consisted by principles, norms, rules of statutory regulations, jurisprudence by judges, agreements and doctrines (teachings) [6].

The data examined are in the form of primary legal materials namely the criminal law (KUHP), jurisprudence, treaties and so on. Whereas secondary legal material, namely all statements, expert comments or arguments, both loose and systematically written in the form of essays, highlights the presence of what is called ius constituendum [6]. For example, the draft law, the draft presidential regulation and so on. The tertiary legal material in the form of an Indonesian encyclopedic, legal dictionary, Kamus Besar Bahasa Indonesia (KBBI), magazines and so on.

\section{Discussion}

\subsection{Enforcement of criminal law in tackling criminal acts of witchcraft in the current positive law.}

Criminal law enforcement is a series of procedures ranging from enforcing the law for any prohibited action to the execution of judges verdict. This understanding is within the broad set of many law enforcement policies. Barda Nawawi Arief stated that the criminal law enforcement policy is a series of processes consisting of three policy stages, namely (1) legislative stages / consist on formulating policies; (2) judicative stages / applying policy stage; and (3) executive / administrative policy phase. Starting from those description it can be said, that the criminal law encforcement policy is consisted in the three powers / authorities, namely legislative / formulative power in determining or formulating what actions can be convicted and what sanctions can be imposed; judicial / applicative power in applying criminal law; and executive / administrative power in implementing criminal law [7]. The power to apply criminal law here is in the hand of law enforcement officials such as the police, prosecutors, courts and even reach to the implementation within the executions stages such as prison. Based on that, law enforcement without a doubt is closely related to criminal policy / criminal politics.

Criminal policy / criminal politics are essentially the rational efforts from community to tackle crime. Crime is a problem that disturbs public order, there will always be a crime inside 
a society and every crimes has its own way of dealing. Therefore, overcoming crime has a true meaning of protecting the community so they might achieve prosperity. The same was stated by Barda Nawawi Arief, that policies to tackle crime are essential essential part of attempts to preserve society (social defense) and to achieve social prosperity (social welfare). Therefore, the ultimate goal in the politics of criminal law is "the safeguarding of society in order to achieve the prosperousness within the people" [8].

Sudarto also stated that criminal politics has a primary function which is reasonable and relatively won't cause problems, in the sense that there cannot be a society that can live directly without those politics product which is a policy. Distinctively with criminal law secondary function, namely the regulation of social control that usually being carried out spontaneously and made by the state with its equipment [9].

As stated in the introduction above, tackling crime can be done both by penal and nonpenal way. Specifically in this case the focus will be on law enforcement by reasoning according to the current legislation. Based on the Criminal Code (KUHP) which not explicitly explained that there is a witchcraft crime inside it, but there are several acts related to witchcraft crime, that being regulated in Articles 545, 546 and 547 of the Criminal Code, namely:

Article 545:

1) Anyone who makes his livelihood, by declare someone's fortune or to make predictions or interpretations of dreams, is threatened with confinement for a maximum of six days or a maximum fine of twenty rupiahs;

2) When committing a violation has not passed by one year of permanent conviction due to the same violation, the penalty can be doubled.

Article 546:

Threatened with a maximum confinement of three months or a maximum fine of three hundred rupiah:

1) Whoever sells, offers, hands over, shares or has stock to sell or distribute, amulets or objects said by him, has supernatural powers;

2) those who study supernatural powers, whose purpose is to create confidence, that they are therefore likely to commit criminal acts without danger to themselves.

Article 547:

A witness, who when asked to provide expert testimony under oath according to the provisions of the law, in court hears using amulets or magic objects, is threatened with a maximum sentence of ten days or a maximum fine of fifteen rupiah.

Based on the above provisions, there are no provisions that prohibit the actions / substance directly to the act of witchcraft, but what is regulated is in those whoever offer, sell amulets or serve an occupation which determining a person's destiny, are the one who can be convicted. By this case, if there are people who commit acts as stated within those regulation by rationally it actually can be proven in the court. However, the substance of the occult acts or witchcraft crime cannot be proven rationally and it is very difficult to determine the factual data and their features.

The difficulty of proving the substance of witchcraft is a problem in this modern world. Indonesian as a cultured nation which follows the development of science and technology does not simply abandon their mystical / occult beliefs such as santet or witchcraft. Within the midst of Indonesian society in certain regions there are those who still believe that a crime might be committed by someone due to acts of witchcraft, so the perpetrators of witchcraft must be 
responsible for the losses that being suffered by victims of witchcraft. There are quite a lot of cases of witchcraft reported to law enforcement officials, but what is often reported is the substance of the occult / mystical deeds and not offering, selling amulets that are said to be of supernatural power which actually regulated in Indonesian Criminal Code, by this law enforcement officials cannot simply catch the alleged perpetrators. The impact occurred persecution and expulsion by the local community to suspected perpetrators of witchcraft.

\subsection{Integration of non-penal and penal acts in tackling witchcraft for the future}

Some areas in Java, such as Banyuwangi and Banten, are often touted as areas that are still thick with the practice of witchcraft. Nevertheless, the phenomenon of santet or witchcraft is not only known in the Java region but in many tribes in Indonesia. In West Java it is called teluhganggaong or sogra. In Bali known as namadesti, leak, or teluhterangjana. In Maluku and Papua under the name namuanguangi. In North Sumatra it is called as beguganjang. In West Sumatra, it is known as puntianak. In Kalimantan, known as perangmaya, and not only in Indonesia, this kind of mysticsm is also happened abroad, such as voodoo practice in Africa. [10].

Every magic has a target and purpose. Based on general classification, magic for practical purposes such as human prosperity or the destruction of another human welfare. Based on these general classifications, magic can be classified into three categories [10]:

1. Productive magic which includes magic for hunting, for fertilizing land, planting and harvesting crops, fishing, shipping, trade and romance;

2. Protective magic includes magic to overcome adversity, debt collecting, maintenance of sick people, safety of travel, and magic to fight against destructive magic;

3. Destructive magic including magic to bring a storm, damage to property rights, magic to bring disease, and magic to bring death.

Relieve capabilities possessed by a Dukun Suwuk for example is a mastery that being pursued and obtained through practice from various sorcery experts. While this capacity of Dukun Prewangan is inherited from their descendants. The mystical being called Prewangan can be passed from one generation to their next generation. This kind of possession inheritance is what becomes the source of ability for a Dukun Prewangan [11].

As mentioned by various examples above, the life of Indonesian people who are so closely related to religio-magical elements is a familiar thing in this country. Moreover, the belief in the existence of supernatural powers themselves has indeed been recognized by various religious values held in society. Ni Luh Gede Yogi Arthani explained several reasons why Indonesian people often ask paranormal help in solving their life's problems, with the following description [12]:

1. As an effort to protect themselves from various kinds of bad things that are invisible such as witchcraft. Personal protection is usually carried out using various amulets that have gone through certain ritual processes;

2. To meet certain objectives, for example, to look authoritative, more handsome, beautiful (attract attention), or so other people give some pity. It can also increase the number of customers in a business;

3. The emergence of strange pain such as sudden speechlessness and pain, but only if you are in a room or at certain hours, where these diseases can not be treated medically but can be cured after going through certain rituals; 
4. Curiosity about the future. Various future predictions are usually made through the method of divination, tarot, face shape and signature form. The various future predictions are then used as material for consideration in making important life decisions;

5. To win a match, obtain a certain position, become a people's representative, or in order to bring down an opponent;

6. For the sake of knowing the message of someone who has passed away, the desire can be in the form of a message from an ancestor or a character in the past

In a public discussion "Article Santet in the Revised Manuscript of the Criminal Code Law" which organized by the Indonesian People's Gerindra Party Faction on April 2, 2013, T. Ronny Nitibaskara, stated that witchcraft in Indonesia was not only institutionalized (institusionalized) but also has been ingrained (internalized). Witchcraft in Indonesian society has been formed as a mechanism to resolve disputes that occur between citizens. Personal conflicts that occur in an unresolved community that have caused quite deep resentment among the parties to the dispute will often be resolved through witchcraft [13].

After reading and examining the various articles which contain magical things contained within the Criminal Code in the previous chapter, then there are some significant differences compared to the regulation of witchcraft contained in the upcoming Criminal Code Draft (RKUHP). One of them is about the criminal threat, where in the old Criminal Code provisions categories of acts that have supernatural elements are more categorized into violations with criminal threats that are less than one year in prison, according to the enactment of these articles in the Third Book on Violations. RKUHP itself basically does not distinguish criminal acts into crime or violation categories.

It is quite correct to say that the provisions regarding the offense of witchcraft in the RKUHP are a constructed form of further development regarding these actions that were previously stipulated in the old KUHP. Moreover, the addition of elements due to actions in the offense in the form of illness, death, or mental or physical suffering can not be found in the serenity in the old Criminal Code. If seen through the comparison it is appropriate if the offense of witchcraft contained in the RKUHP is a new form of action that has not been regulated further in the old KUHP, so that if it can be categorized into the process of criminalization of an act that was not previously threatened by a criminal act which then turns into a threatened act.

In Article 252 of the Criminal Code Draft, it is stated that the actions regulated there are only in the form of recognition from someone who feels that he has supernatural powers and that his power can then help someone else in trying to cause something bad to someone else. Thus the offense regulates the participation of third parties in committing a crime. The third parties who have this magical power can also be referred to as a psychic, shaman, or other designations contained in the traditions of society.

Referring to Barda Nawawi Arief opinion, criminalization efforts related to the offense of witchcraft in RKHUP basically tend to focus more on regulating efforts to prevent actions taken by sorcerers. Due to the criminalization of acts of offering or providing services through the witchcraft to kill or harm someone. This form of regulation itself has weaknesses due to the lack of a strict regulatory concept and its elements are quite difficult to fulfill, due to the element of "recognition of having supernatural powers" [14]. This vague formulation is often misinterpreted by many parties, that what will be criminalized is the offense of "murder / ill- 
treatment with witchcraft", whereas in its consideration it is not easy to prove the causal relationship between acts of witchcraft with the onset of death or suffering other people [14].

Criminal imprisonment could also be a criminal factor, since it relies heavily on criminal law as the first response in dealing with crime, which means overestimating the ability of the criminal law itself, that have so many limitations. Meanwhile, non-penal actions could become quite more effective and can support another penal actions inside the framework of criminal politics and social politics [15]. There is also other alternative options to prevent the emergence of criminogenic factors as a result of criminal conviction, for example by avoiding criminal justice processes and applying selective and limitative criminal law [15].

The approach of economic analysis within the formulation of law and law enforcement is the beginning part within the introduction of the analysis regarding criminal law using rational choice theory. The essence of this theory is that, each criminal offense has calculated the benefits of their actions in excess of losses as a result of his actions. Basically this make a punishment will only resulted in the losses of the perpetrators of crime but does not provide "benefits" to victims of their criminal acts either, this kind of cases usually happen in corruption cases within the state [16].

The criminal matters are inseparable from the meaning of criminal acts and criminal responsibility, while the identification of criminal responsibility is always based on the interests of monodualistic balance way of thinking, namely the balance of community interests with individual interests, including subjective and objective interests [17]. The function of criminal law is to protect as well as to maintain the balance of various interests (community, state, perpetrators of crime and victims of criminal acts). At this moment there is a development within the science of criminal law and criminology, i.e. their attention that not only directed at crime and its offenders as happened in the past, but also to people other than them, namely, victims, bystanders, and any other members of the community [18].

According to Muladi [19], in the regulation of criminal offenses, the implementation of a balanced idea should be seriously being concerned, namely:

1. The balance between institutional morality; social morality and individual morality;

2. The balance between "individual rights" and "collective rights";

3. The balance between the interests of the offender and the victim;

4. The balance between objective aspects (actions) with subjective aspects (mental attitude);

5. The balance between legal certainty, flexibility and fairness;

6. The balance between national values and universal values;

7. The balance between formal legality and material legality that gives room to the living law, which is sourced from:

a. post-independence legislative policies;

b. scientific interactions and agreements in various national scientific meetings;

c. sociological aspirations;

d. universal aspiration of civilized society

\section{Conclusion}


In conclusion, crime prevention has not been able to comprehensively address the crime of witchcraft, while the criminal law enforcement alone tends to be repressive, partial problem solving, with a high cost and if being used inappropriately can became a major threat in human life. That is because the crime of witchcraft is a mystical, irrational and very contradictory action in the midst of modern society that always requires facts and data which made those kind of act became difficult to prove in the court. Therefore a combination of non-penal and penal action is still needed, with the provision that non-penal measures take a first precedence to prevent the public from being vigilant towards perpetrators. The non-penal concretization in overcoming this criminal acts of witchcraft could also by involving police officers, community leaders and religious leaders to reprimand and ordered the perpetrators to stop doing witchcraft activities by way of deliberation. However, if they still conducts witchcraft activities, then only use the means of punishment by arresting and processing the perpetrators to be proven in court. Thus, there is a warning beforehand as a form of non-penal conflict resolution, but if this action are not working, the case will be processed by law enforcement officials in court as a means of resolving in a penal manner. Non-penal and penal integration in dealing with the crime of witchcraft is more selective and just, in solving this problem within the community.

\section{References}

[1] E. Herniti, "Kepercayaan Masyarakat Jawa Terhadap Santet, Wangsit, dan Roh Menurut Perspektif Edwards," Thaqafiyyaht; Jurnal Bahasa, Peradaban dan Informasi Islam, vol. 13, no. 2, pp. 384-400, 2012.

[2] K. B. B. I. (KBBI), "Santet," [Online]. Available: https://www.kbbi.web.id/santet. [Accessed 1962020 ].

[3] M. W. Dictionary, "Witchcraft," [Online]. Available: https://www.merriam-webster.com/dictionary/witchcraft. [Accessed 196 2020].

[4] Dictionary, "Occult," [Online]. Available: https://www.dictionary.com/browse/occult?s=t. [Accessed 1962020 ].

[5] Pondsius and . S. Takaliuang, Antara Kuasa Gelap dan Kuasa Terang, Batu: Departemen Literatur YPPII, 2004, p. xvi.

[6] M. F. ND and Y. Achmad, Dualisme Penelitian Hukum Normatif \& Empiris, Yogyakarta: Pustaka Pelajar, 2010 , p. 34.

[7] B. N. Arief, Kapita Selekta Hukum Pidana Tentang Sistem Peradilan Pidana (Integrated Criminal Justice System), Semarang: BP Undip, 2011, pp. 18-19.

[8] B. N. Arief, Bunga Rampai Kebijakan Hukum Pidana Perkembangan Penyusunan Konsep KUHP Baru, Jakarta: Kencana Prenada Media Grup, 2010, p. 4.

[9] Sudarto, Hukum dan Hukum Pidana, Bandung: Alumni, 2007, p. 150.

[10] N. Falikhah, "Santet dan Antropologi Agama," Alhadharah: Jurnal Ilmu Dakwah, vol. 11, no. 22, pp. 129-138, 2012.

[11] R. T. Arini, M. . Y. Alimi and G. , "The Role of Dukun Suwuk and Dukun Prewangan in Curing Diseases in Kediri Community," International Journal of Indonesian Society and Culture, vol. 8, no. 2, pp. 328-338, 2016.

[12] N. L. G. Yogi Arthani, "Praktek Paranormal dalam Kajian Hukum Pidana di Indonesia," Jurnal Advokasi, vol. 5, no. 1, pp. 30-40, 2015.

[13] R. T. Nitibaskara, "Santet dalam Perkembangan Hukum Indonesia," Diskusi Publik Pasal Santet dalam Naskah Revisi UU, p. ., 2 April 2013.

[14] B. N. Arief, Kapita Selekta Hukum Pidana, Bandung: Citra Aditya Bakti, 2013, p. 293. 
[15] G. Aryadi, "Alternatif Penjatuhan Pidana Sebagai Upaya Pencegahan Faktor Kriminogen," Jurnal Hukum Ius Quia Iustum, vol. 9, no. 21, pp. 54-66, 2002.

[16] R. Atmasasmita, "Asset Recovery dan Mutual Assistance In Criminal Matters," Makalah Untuk Pelatihan Hukum Pidana, Kerjasama Mahupiki Dan Fakultas Hukum UGM, pp. 1-26, 23 - 27 February 2014.

[17] . I. S. Adji, "Administrative Penal Law: "Kearah Konstruksi Pidana Limitatif”," Bahan Untuk Pelatihan Hukum Pidana, Kerjasama Mahupiki dan Fakultas Hukum UGM, pp. 1-27, 23 - 27 February 2014.

[18] E. Sopoyono, "Kebijakan Perumusan Sistem Pemidanaan Yang Berorientasi Pada Korban," Jurnal Masalah-Masalah Hukum, vol. 41, no. 1, pp. 29-41, 2012.

[19] Muladi, "Beberapa Catatan Terhadap RUU KUHP," in Beberapa Tulisan Terkait Kebijakan Kriminal dalam RUU KUHP, Jakarta, Democratic Reform Support Program (RRSP) dan Aliansi Nasional Reformasi KUHP, 2006, p. 10. 